\title{
Prevalence of abdominal symptoms in the Polish population
}

\author{
Epidemiologia dolegliwości brzusznych w polskiej populacji
}

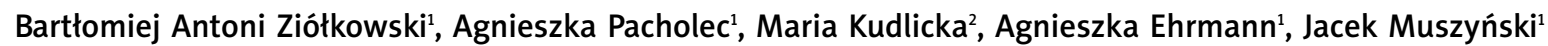 \\ 1Department of Gastroenterology and Metabolic Diseases, Medical University of Warsaw, Poland \\ 2County Hospital, Otwock, Poland
}

Przegląd Gastroenterologiczny 2012; 7 (1): 20-25

DOI: $10.5114 / p g .2012 .27218$

Key words: abdominal symptoms, dyspepsia, gastroesophageal reflux disease, irritable bowel syndrome, prevalence.

Słowa kluczowe: dolegliwości brzuszne, dyspepsja, choroba refluksowa przełyku, zespół jelita drażliwego, chorobowość.

\begin{abstract}
Address for correspondence: Bartłomiej Antoni Ziółkowski MD, PhD, Department of Gastroenterology and Metabolic Diseases, Medical University of Warsaw, 1a Banacha, 02-097 Warsaw, Poland, phone: +48 225992838 , fax: +48 225991838 , e-mail: bziolkow@gmail.com
\end{abstract}

\begin{abstract}
Introduction: There are no published data on the prevalence of common gastrointestinal disorders such as dyspepsia, gastroesophageal reflux disease (GERD), irritable bowel syndrome (IBS), constipation and bloating in the Polish population.

Aim: The aim of this study was to determine the prevalence of these most common abdominal symptoms.

Material and methods: The study involved a population sample aged 21 years or older from a medium-sized city. A total of 850 people (age range: 21-76 years) were interviewed. Demographic and anthropometric data, symptoms specific to dyspepsia, GERD, constipation, diarrhoea, bloating, IBS, as well as nutritional habits, alcohol and tobacco use, and presence of concomitant diseases were studied in a face-to-face interview.

Results: Approximately 23\% of participants suffered from dyspepsia, $36 \%$ had GERD, constipation was present in $13 \%$ of participants, and bloating in 31\%. Only 7 participants reported chronic diarrhoea and $13 \%$ of participants had IBS symptoms. All the above-mentioned complaints were slightly more common in diabetic patients, but the difference was not significant.

Conclusions: The prevalence of gastrointestinal symptoms in the Polish population is high, and similar to the rates reported by investigators from other countries.
\end{abstract}

\section{Streszczenie}

Wstęp: Dane dotyczące chorobowości z powodu najczęstszych dolegliwości brzusznych pochodzą najczęściej z publikacji zagranicznych. Nie ma opublikowanych danych na temat częstości występowania tych dolegliwości w polskiej populacji. Cel: Określenie częstości występowania dolegliwości brzusznych oraz takich zespołów chorobowych, jak choroba refluksowa przełyku (gastroesophageal reflux disease - GERD), dyspepsja, zespół jelita drażliwego (irritable bowel syndromeIBS), zaparcie i wzdęcie.

Materiat i metody: Grupę badaną stanowiło 850 osób (wiek badanych: 21-76 lat), losowo wybranych mieszkańców miasta o średniej wielkości, którzy ukończyli 21 lat. Badanie przeprowadzał odpowiednio przeszkolony ankieter. Ankieta składała się z pytań dotyczących danych demograficznych, antropometrycznych, zwyczajów żywieniowych, dolegliwości brzusznych (dyspepsja, GERD, IBS, wzdęcie, zaparcie, biegunka), liczby wizyt u lekarza, chorób towarzyszących oraz wywiadów rodzinnych. Wyniki uzyskane na podstawie kwestionariusza zapisano w formie arkusza kalkulacyjnego Excel, a następnie poddano analizie statystycznej.

Wyniki: U blisko $23 \%$ badanej grupy rozpoznano dyspepsję, a u $36 \%$ GERD. Na zaparcie cierpiało 13\% osób, natomiast wzdęcie występowało u 31\% ankietowanych. Przewlekłą biegunkę rozpoznano u 7 pacjentów, a IBS u 13\% osób. Chorzy na cukrzycę zgłaszali dolegliwości brzuszne nieznacznie częściej niż osoby ankietowane bez cukrzycy.

Wnioski: Częstość występowania dolegliwości brzusznych w polskiej populacji jest duża i nie różni się istotnie do danych pochodzących z innych krajów. 


\section{Introduction}

There are no published data on the prevalence of the most common gastrointestinal symptoms such as dyspepsia, gastroesophageal reflux disease (GERD), irritable bowel syndrome (IBS), constipation and bloating in the Polish population. Data concerning the prevalence of these most common gastrointestinal complaints come from studies performed abroad. Apart from a single presentation, regarding the prevalence of GERD, no data reflecting the scale of the problem in the Polish population have been reported to date [1].

Dyspepsia is most commonly defined as a set of symptoms including abdominal pain, burning or abdominal discomfort (early satiety, postprandial fullness, bloating or nausea). Usually, a number of the above symptoms are present in dyspeptic patients, and in different patients they may appear in different constellations. According to published data from other countries, dyspeptic symptoms are very common and it is estimated that up to $20-30 \%$ of the population may suffer from this condition $[2,3]$. The economic burden of dyspepsia is high, considering the fact that at least half of dyspeptic patients are health care seekers [4].

From the epidemiological point of view, dyspepsia can be divided into investigated and uninvestigated dyspepsia. According to aetiology, patients with dyspepsia can be divided in two categories: those whose symptoms are due to an organic or metabolic cause and those without any identifiable explanation of the symptoms. The latter is known as idiopathic or functional dyspepsia, and nowadays it should be recognized based on the Rome III criteria [5].

Another frequent upper gastrointestinal tract condition is gastroesophageal reflux disease (GERD). According to the Montreal definition, GERD is a condition in which "the reflux of stomach contents causes troublesome symptoms and/or complications." Symptoms are considered troublesome if they have a negative impact on the quality of life $[6,7]$. According to the Montreal definition, episodic heartburn should be differentiated from GERD. If episodes of heartburn are infrequent and not severe enough to have a negative impact on an individual's well-being, GERD cannot be diagnosed. It is estimated that $7-10 \%$ of the population experience main reflux symptoms on a daily basis, approximately $12-20 \%$ once a week and about $15-25 \%$ once per month [8]. The study by Reguła mentioned above has shown that up to $34 \%$ of adult patients seeing their general practitioners for any reason had symptoms of GERD [1].

Bloating is a sensation of abdominal distension, and it may be - but does not have to be - part of another functional bowel or gastrointestinal disorder. It is esti- mated that more than $90 \%$ of IBS patients report bloating as one of the symptoms [9]. Conducted surveys have demonstrated that up to $30 \%$ of the population report bloating, and the symptom is more common in women $[10,11]$. Bloating adversely affects the quality of life and it is believed by some patients to be an important alarm symptom [12].

Constipation is commonly defined as fewer than 3 bowel movements per week, or excreting lumpy or hard stools. Other symptoms include straining, incomplete evacuation or manual manoeuvres facilitating defecation. Loose stools are not frequent, unless laxatives are used. The prevalence of constipation has been estimated at up to $27 \%$ of the population, more commonly afflicting women [13].

Diarrhoea is defined as loose or watery stools and/or more than 3 bowel movements per day, sometimes with urgency. It is estimated that chronic diarrhoea affects $2-5 \%$ of patients in general practice [14].

Irritable bowel syndrome is a frequent functional disorder with dominating pain or discomfort, relieved by defecation or associated with an alteration in the frequency and/or consistency of stools [9]. Irritable bowel syndrome is a frequent reason for absenteeism and alters the quality of life of the patients. It is estimated that the prevalence of IBS is high, ranging from $7 \%$ to $13 \%$, or even $20 \%$ of the population. According to estimates, IBS is more frequent in women $[15,16]$.

\section{Aim}

In this study we aimed to determine the prevalence of these most common abdominal complaints in the Polish population and analyse it with regard to age, sex, nutritional habits, education and body mass index (BMI). The study was performed on a sample of the population of a mid-sized city.

\section{Material and methods}

A random sample of 1,100 inhabitants was drawn from the registry of the population of the city of Otwock (43,000 inhabitants). The individuals who agreed to participate in the study qualified as respondents if they were over 18 years old, mentally competent to be interviewed, able to understand, write and read in Polish. Out of the 1,100 inhabitants 69 (6\%) could not be contacted or did not meet the above-mentioned criteria and 182 (17\%) declined to take part in the study. The remaining 850 subjects, aged 21-76 years, were interviewed faceto-face by trained interviewers between the years 2002 and 2009. Each of the participants anonymously answered a questionnaire consisting of questions concerning demographic and anthropometric data, symp- 
toms specific to dyspepsia, GERD, constipation, diarrhoea, bloating, IBS, as well as nutritional habits, alcohol and tobacco use, presence of concomitant diseases and frequency of medical care utilisation. Subsequently, the data were entered into a Microsoft Office Excel 2007 database and then statistically analysed. The inserted data were statistically assessed using the methods of approximate confidence intervals, confidence intervals and one-sided confidence intervals, as well as confidence intervals for percentage non-conforming. All the intervals were constructed at $1-\alpha=0.99$ confidence level. Moreover, hypothesis verification procedures were applied: the null hypothesis of equality of two percentages - an approximation test; and the null hypothesis of no relationship between the measured features $-a \chi^{2}$ test for independence. The Yates' correction was used in $2 \times 2$ tables. All the null hypotheses were verified at a significance level of $\alpha=0.01$.

\section{Results}

A total of 850 people (age range: $21-76$ years) were interviewed between 2002 and 2009, which accounted for $2 \%$ of the population of Otwock. Women comprised $60 \%$ of the group $(n=510)$. All respondents were white. Sixty-three percent were married; two respondents did not indicate their marital status. The majority had completed at least high school education. In our study $67 \%$ of respondents were professionally active, while the remaining 33\% declared another source of income (old age pension, disability pension or other benefits). Thirty percent of respondents were younger than 39 years, and $61 \%$ were $40-65$ years old. Subjects older than 66 years made up $9 \%$ of the group. $49.8 \%(n=423)$ of subjects were within the normal BMI range (BMI 18.5-24.9 $\left.\mathrm{kg} / \mathrm{m}^{2}\right)$, while $14.5 \%(n=123)$ of respondents were obese (BMI over $\left.30 \mathrm{~kg} / \mathrm{m}^{2}\right)$. Thirty-six percent $(n=307)$ of respondents smoked cigarettes; smoking was more common in men $(50 \%, n=171)$ than in women $(27 \%$, $n=136$ ). Diabetes (of any type) was present in $14.6 \%$ of respondents ( $n=124)$. 67\% of respondents reported following regular meal times, men being less regular than women (men: 61\%, female: $72 \%$; $p$-value < 0.01). Frequent consumption of fruits and vegetables was reported by $27 \%$ of men and $46 \%$ of women ( $p$-value $<0.01$ ). Wholemeal bread consumption was similar in both sexes. More commonly meat was a predominant ingredient in the diet of male subjects (men: $60 \%$, female: $42 \%$; $p$-value $<0.01$ ). One hundred and twenty respondents (14\%) reported eating out, more commonly men (men: $18 \%$, female: $11 \%$; $p$-value $<0.01$.

Since the aim of this study was to determine the prevalence of both investigated and uninvestigated dyspepsia in the Polish population, the Rome III criteria were not applied. Except for the criterion of pain or discomfort, dyspepsia was recognized in patients who met the criterion of time and frequency of the symptoms, which means symptoms occurring in the last 6 months preceding the study with a frequency of at least once a week. According to these criteria, dyspepsia was recognized in 197 participants (23\%). Eighty-one respondents $(10 \%)$ suffered from dyspepsia at least half of the time during the preceding 6 months. The prevalence of dyspepsia in men and women was similar (men: $21 \%$, female: $25 \%$ ). $67.5 \%$ of dyspeptic patients $(n=133)$ sought medical advice. In women the prevalence of dyspepsia increased with age ( $p$-value $<0.01)$. Details are given in Table I. One hundred and fourty-one dyspeptic respondents (72\%) described themselves as irritable, while only $47 \%$ of non-dyspeptic respondents reported this disposition ( $p$-value $<0.01$ ). No link was found between the prevalence of dyspepsia and BMI (Table II).

Gastroesophageal reflux disease was recognized in patients who gave affirmative answers to the following questions:

- Do you experience episodes of heartburn/burning in the chest?

- Is your well-being influenced by heartburn?

Table I. Prevalence of abdominal symptoms according to age and sex

Tabela I. Częstość występowania dolegliwości brzusznych w zależności od płci i wieku

\begin{tabular}{|c|c|c|c|c|c|c|c|c|c|c|}
\hline \multirow{3}{*}{$\begin{array}{l}\text { Age } \\
\text { [years] }\end{array}$} & \multicolumn{10}{|c|}{ Prevalence of abdominal symptoms [\%] } \\
\hline & \multicolumn{2}{|c|}{$\begin{array}{c}\text { Dyspepsia } \\
23.2\end{array}$} & \multicolumn{2}{|c|}{$\begin{array}{c}\text { GERD } \\
35.5\end{array}$} & \multicolumn{2}{|c|}{$\begin{array}{c}\text { Bloating } \\
31.4\end{array}$} & \multicolumn{2}{|c|}{$\begin{array}{c}\text { Constipation } \\
13.4\end{array}$} & \multicolumn{2}{|c|}{$\begin{array}{l}\text { IBS } \\
12.9\end{array}$} \\
\hline & $\begin{array}{c}M \\
(n=72) \\
21.2\end{array}$ & $\begin{array}{c}\mathrm{F} \\
(n=125) \\
24.5\end{array}$ & $\begin{array}{c}M \\
(n=125) \\
36.8\end{array}$ & $\begin{array}{c}\mathrm{F} \\
(n=177) \\
34.7\end{array}$ & $\begin{array}{c}M \\
(n=81) \\
23.8\end{array}$ & $\begin{array}{c}F \\
(n=186) \\
36.5\end{array}$ & $\begin{array}{c}M \\
(n=31) \\
9.1\end{array}$ & $\begin{array}{c}\mathrm{F} \\
(n=83) \\
15.4\end{array}$ & $\begin{array}{c}M \\
(n=44) \\
12.9\end{array}$ & $\begin{array}{c}\mathrm{F} \\
(n=66) \\
12.9\end{array}$ \\
\hline $18-29$ & 14.3 & 15.3 & 28.6 & 27.1 & 3.6 & 32.2 & 0.0 & 18.6 & 7.1 & 10.2 \\
\hline $30-39$ & 17.7 & 17.8 & 30.6 & 22.8 & 12.9 & 30.7 & 6.5 & 13.9 & 6.5 & 6.9 \\
\hline $40-65$ & 23.2 & 24.7 & 38.6 & 36.3 & 27.3 & 37.0 & 10.5 & 15.3 & 15.5 & 12.7 \\
\hline $65+$ & 20.0 & 48.0 & 43.3 & 58.0 & 40.0 & 50.0 & 13.3 & 24.0 & 13.3 & 30.0 \\
\hline
\end{tabular}


Table II. Prevalence of abdominal symptoms according to sex, presence of obesity $\left(\mathrm{BMI}>30 \mathrm{~kg} / \mathrm{m}^{2}\right)$ and diabetes mellitus (DM)

Tabela II. Częstość występowania dolegliwości brzusznych w zależności od płci, wspótistniejącej otyłości $\left(B M I>30 \mathrm{~kg} / \mathrm{m}^{2}\right)$ oraz cukrzycy

\begin{tabular}{|c|c|c|c|c|c|c|c|c|c|c|}
\hline \multirow[t]{3}{*}{ Characteristics } & \multicolumn{10}{|c|}{ Prevalence of abdominal symptoms [\%] } \\
\hline & \multicolumn{2}{|c|}{$\begin{array}{c}\text { Dyspepsia } \\
23.2\end{array}$} & \multicolumn{2}{|c|}{$\begin{array}{l}\text { GERD } \\
35.5\end{array}$} & \multicolumn{2}{|c|}{$\begin{array}{c}\text { Bloating } \\
31.4\end{array}$} & \multicolumn{2}{|c|}{$\begin{array}{c}\text { Constipation } \\
13.4\end{array}$} & \multicolumn{2}{|c|}{$\begin{array}{l}\text { IBS } \\
12.9\end{array}$} \\
\hline & $\begin{array}{c}M \\
(n=72) \\
21.2\end{array}$ & $\begin{array}{c}\mathrm{F} \\
(n=125) \\
24.5\end{array}$ & $\begin{array}{c}M \\
(n=125) \\
36.8\end{array}$ & $\begin{array}{c}\mathrm{F} \\
(n=177) \\
34.7\end{array}$ & $\begin{array}{c}M \\
(n=81) \\
23.8\end{array}$ & $\begin{array}{c}F \\
(n=186) \\
36.5\end{array}$ & $\begin{array}{c}M \\
(n=31) \\
9.1\end{array}$ & $\begin{array}{c}\mathrm{F} \\
(n=83) \\
15.4\end{array}$ & $\begin{array}{c}M \\
(n=44) \\
12.9\end{array}$ & $\begin{array}{c}\mathrm{F} \\
(n=66) \\
12.9\end{array}$ \\
\hline $\begin{array}{l}\text { Respondents with } \\
\mathrm{BMI}<29.9 \mathrm{~kg} / \mathrm{m}^{2}\end{array}$ & 22.3 & 23.8 & 37.6 & 34.2 & 23.7 & 35.1 & 6.6 & 15.9 & 13.9 & 12.6 \\
\hline $\begin{array}{l}\text { Respondents with } \\
\mathrm{BMI}>30 \mathrm{~kg} / \mathrm{m}^{2}\end{array}$ & 16.7 & 29.8 & 33.3 & 38.6 & 24.2 & 47.4 & 19.7 & 19.3 & 9.1 & 15.8 \\
\hline Respondents without DM & 20.6 & 23.4 & 37.2 & 32.9 & 23.4 & 34.9 & 8.9 & 14.6 & 12.8 & 11.0 \\
\hline Respondents with DM & 24.1 & 31.8 & 34.5 & 47.0 & 24.6 & 46.2 & 10.3 & 27.3 & 13.8 & 24.6 \\
\hline
\end{tabular}

- Is your heartburn/burning in the chest relieved by antacids?

- Do you experience regurgitations of food to your mouth?

- Do you experience regurgitations of bile or bitter taste in your mouth?

- Have you experienced these symptoms at least 4 days during the preceding week?

Recognition of GERD was limited to patients who gave affirmative answers to at least 3 of the above questions, on condition that the patient confirmed heartburn or burning-in-the-chest episodes. Gastroesophageal reflux disease criteria were met in 302 respondents (35.5\%). Differences between the sexes were not significant (Table I; men: 37\%, female: 35\%). In women the prevalence of GERD increased with age and BMI ( $p$-value $<0.01)$. There was no increase in the prevalence of GERD in obese men (Table II).

Thirty-six percent of respondents with GERD consulted a physician. Eighty-one percent of respondents with GERD $(n=246)$ gave an affirmative answer to the question "Are you an irritable person?" Among those without GERD only $36 \%$ described themselves as irritable ( $p$-value < 0.01). For both dyspepsia and GERD, no difference was found with regard to education, regularity of meals, frequency of fruit and vegetable consumption or the predominant ingredient in the diet.

Recognition of constipation was limited to respondents who had fewer than 3 bowel movements per week, and reported excreting lumpy or hard stools. Exclusion criteria for constipation were urgency and mushy or watery stools. Constipation was recognized in $13.4 \%$ of respondents $(n=114)$ and it was more common in women (men: $9 \%$, female: $15 \%$; $p$-value $<0.01$ ). Constipation was more common in obese men (men
$\mathrm{BMI}>30 \mathrm{~kg} / \mathrm{m}^{2}:$ 20\%; men $\mathrm{BMI}<30 \mathrm{~kg} / \mathrm{m}^{2}: 7 \%$; $p$-value $<0.01)$. Details are given in Table II. No difference was found with regard to education, regularity of meals, frequency of fruit and vegetable consumption or the predominant ingredient in the diet. Twenty-two percent of respondents with constipation consulted their physician for their symptoms. Sixty-three percent of respondents with constipation ( $n=72$ ) gave an affirmative answer to the question "Are you an irritable person?" Among those without constipation 51\% described themselves as irritable (NS).

Recognition of chronic diarrhoea was limited to patients having at least 3 loose stools per day and reporting mushy and watery stools for a period longer than 4 weeks. These criteria were satisfied only in 7 participants (less than $1 \%$ of respondents), so we did not analyse this group.

Bloating was recognized in $31 \%$ of respondents $(n=267)$, who answered affirmatively to the question "Do you have a frequent feeling of bloating?" This symptom was more common in women (men: $24 \%$, female: $36 \%$; $p$-value $<0.01)$. In men the prevalence of bloating increased with age ( $p$-value $<0.01$, Table I). No difference was found with regard to $\mathrm{BMI}$, education, regularity of meals, frequency of fruit and vegetable consumption or the predominant ingredient in the diet. Twenty-three percent of respondents suffering from bloating consulted a physician. Eighty-four percent of respondents with bloating ( $n=223)$ gave an affirmative answer to the question "Are you an irritable person?" Among those without bloating only $38 \%$ described themselves as irritable ( $p$-value $<0.01)$.

Our study was designed in the year 2000. The Rome III criteria were developed in 2006 [9]. Because of that, the Manning criteria were used to recognize IBS. Irrita- 
ble bowel syndrome was recognized in 110 persons, i.e. $13 \%$ of respondents, equally in men and women (Table I). In women the prevalence of IBS increased according to age ( $p$-value < 0.01). No difference was found with regard to $\mathrm{BMI}$, education, regularity of meals, frequency of fruit and vegetable consumption or the predominant ingredient in the diet. Twenty-five percent of respondents suffering from IBS consulted a physician. Eightyeight percent of respondents with IBS $(n=97)$ gave an affirmative answer to the question "Are you an irritable person?" Among those without IBS, 47\% described themselves as irritable ( $p$-value $<0.01)$.

It appears remarkable that in all the described conditions except for constipation, i.e. dyspepsia, GERD, bloating and IBS, respondents suffering from a specific symptom more often described themselves as irritable as compared to those without the symptom. It seems worth mentioning as well that all the examined symptoms were slightly more common in diabetic patients, but the differences were not statistically significant (Table II).

\section{Discussion}

As previously mentioned, there are no data concerning the epidemiology of the most common gastrointestinal symptoms in Poland. Apart from the one presentation referred to above [1], the authors are not aware of any study which could shed some light on this subject. The results of this study demonstrate that even though Poland is more homogeneous in its ethnicity than many Western countries, prevalence of these symptoms is very similar [2, 3].

Comparing the data from our study with the results of a national census or epidemiological studies held in different fields of medicine confirms that the studied sample was representative for Poland and reflected the actual social structure $[17,18]$. As in other surveys, women were represented in the majority and comprised $60 \%$ of the sample $[10,18,19]$.

As previously stated, dyspeptic complaints affect up to $20-30 \%$ of the population, but certainly they differ between continents and countries [2,3]. In our study sample, dyspepsia (pain or discomfort in the upper abdomen, postprandial fullness, early satiety, belching or nausea) was present in $23 \%$ of respondents. Sandler et al. found very similar prevalence of abdominal pain or discomfort in a sample of 2,510 respondents from the United States. Dyspeptic complaints were present in $22 \%$ of respondents within the month before the interview [10].

According to a review by Koloski et al., $14-84 \%$ of people suffering from abdominal symptoms consulted a physician for abdominal problems in the year preced- ing the review [4]. In our study, during the 6 months preceding the interview $68 \%$ of patients suffering from dyspepsia consulted their physicians. Patients with GERD, constipation, bloating and IBS consulted their physicians in $36 \%, 22 \%, 23 \%$ and $25 \%$ of cases, respectively.

Gastroesophageal reflux disease was recognized in $36 \%$ of respondents, which is very close to the unpublished study mentioned above [1]. Taking into account data from the national census, according to which Poland has 29.4 million adult citizens, it can be estimated that the problem of GERD concerns more than 10 million Polish adults [17]. In Western countries, $4-10 \%$ of the population experience heartburn daily, and up to $20 \%$ have reflux symptoms once a week $[8,19,20]$. However, the methodology of these studies differs from the one used in our study, which can make the comparison a little difficult. In our sample, GERD was insignificantly more common in men. The prevalence of GERD increased significantly with age and BMI in female subjects.

With regard to race and dietary habits, the prevalence of constipation can differ and it is estimated that it can range from $6 \%$ to $20 \%$ [21-23]. In Canada it has been found that constipation affects up to $27 \%$ of respondents, more commonly females, of non-white ethnic origin, and its prevalence increases with age [13]. In our study, constipation was present in $13.4 \%$ of respondents and its prevalence in men increased with BMI.

As previously stated, chronic diarrhoea affects $2-5 \%$ of respondents, but in our study less than $1 \%$ met the criteria allowing this condition to be recognized.

Bloating is said to afflict $16-30 \%$ as an independent symptom or as part of IBS [9-11]. In Sandler et al.'s paper, the ratio of female to male bloating sufferers was $2: 1$ [10]. In our study, this ratio was $3: 2$. Interestingly, unlike in Sandler's survey we noted that the prevalence of bloating increased with respect to age. The trend was observed in both sexes but was significant in men only (Table I).

According to the criteria used, IBS was recognized in 110 respondents, which makes up $13 \%$ of the sample. Surprisingly, the percentage of men and women suffering from IBS was almost identical. It is known that in other countries the disease is more common in women and affects $7 \%$ to $20 \%$ of respondents $[15,16]$. As stated above, the Rome III criteria were not applied since the study was designed in the year 2000. Anyway, an attempt to divide IBS into recommended subtypes (IBS with diarrhoea, constipation, unsubtyped or mixed) failed since the group of respondents with IBS was relatively small. The prevalence of IBS increased with age, and it was significant in women (Table I). However, it is 
necessary to remember that in all the surveys such estimates should be treated with judiciousness since it is not possible to exclude an organic disease by means of endoscopy or even laboratory findings. Even though this study shows a high prevalence of abdominal complaints, it is limited by poor knowledge on the aetiology of the presented symptoms.

We have not observed any significant differences as regards the regularity of meals, nor the predominant diet ingredients, the kind of ingested bread or the level of education. The common trait for all symptoms apart from constipation was that respondents suffering from a specific condition described themselves as irritable significantly more often than the respondents without the specific condition. This reflects how gastrointestinal symptoms can be strongly affected by psychosocial factors.

\section{Acknowledgments}

The authors received no financial support from any person or institution.

\section{References}

1. Reguła J. Epidemiologia choroby refluksowej w Polsce. Materiały IX Warszawskich Spotkań Gastroenterologicznych [Polish]. Warszawa, 2003; 22-5.

2. Talley NJ, Zinsmeister AR, Schleck CD, Melton LJ 3rd. Dyspepsia and dyspepsia subgroups: a population-based study. Gastroenterology 1992; 102: 1259-68.

3. Agréus L, Svärdsudd K, Nyrén O, Tibblin G. Irritable bowel syndrome and dyspepsia in the general population: overlap and lack of stability over time. Gastroenterology 1995; 109: 671-80.

4. Koloski NA, Talley NJ, Boyce PM. Predictors of health care seeking for irritable bowel syndrome and nonulcer dyspepsia: a critical review of the literature on symptom and psychosocial factors. Am J Gastroenterol 2001; 96: 1340-9.

5. Tack J, Talley NJ, Camillieri M, et al. Functional gastroduodenal disorders. Gastroenterology 2006; 130: 1466-79.

6. Vakil N, van Zanten SV, Kahrilas P, et al.; Global Consensus Group. The Montreal definition and classification of gastroesophageal reflux disease: a global evidence based consensus. Am J Gastroenterol 2006; 101: 1900-20.

7. Kahrilas PJ, Shaheen NJ, Vaezi MF, et al.; American Gastroenterological Association. American Gastroenterological Association Medical Position Statement on the management of gastroesophageal reflux disease. Gastroenterology 2008; 135: 1383-91.

8. Kahrilas PJ, Pandolfino JE. Gastroesophageal reflux disease and its complications, including Barrett's metaplasia. In: Gastrointestinal and liver disease. 7th ed. Vol. 1. Feldman M, Friedman LS, Sleisenger MH. Saunders, Elsevier Science, Philadelphia 2002; 599-623.

9. Longstreth GF, Thompson WG, Chey WD, et al. Functional bowel disorders. Gastroenterology 2006; 130: 1480-91.

10. Sandler RS, Stewart WF, Liberman JN, et al. Abdominal pain, bloating, and diarrhea in the United States: prevalence and impact. Dig Dis Sci 2000; 45: 1166-71.
11. Talley NJ, Boyce P, Jones M. Identification of distinct upper and lower gastrointestinal symptom groupings in an urban population. Gut 1998; 42: 690-5.

12. Harewood GC, Murray F, Patchett S, et al. Assessment of colorectal cancer knowledge and patient attitudes towards screening: is Ireland ready to embrace colon cancer screening? Ir J Med Sci 2009; 178: 7-12.

13. Pare P, Ferrazzi S, Thompson WG, et al. An epidemiological survey of constipation in Canada: definitions, rates, demographics, and predictors of health care seeking. Am J Gastroenterol 2001; 96: 3130-7.

14. Fine KD, Schiller LR. AGA technical review on the evaluation and management of chronic diarrhea. Gastroenterology 1999; 116: 1464-86.

15. Saito YA, Schoenfeld P, Locke GR 3rd. The epidemiology of irritable bowel syndrome in North America: a systematic review. Am J Gastroenterol 2002; 97: 1910-5.

16. Drossman DA, Camilleri M, Mayer EA, Whitehead WE. AGA technical review on irritable bowel syndrome. Gastroenterology 2002; 123: 2108-31.

17. Raport z wyników Narodowego Spisu Ludności i Mieszkań, Główny Urząd Statystyczny, 2002 http://www.stat.gov.pl/cps/ rde/xbcr/gus/PUBL_raport_z_wynikow_nsp_ludnosci_i_miesz kan_2002.pdf

18. Zdrojewski T, Bandosz P, Szpakowski P. i wsp. Rozpowszechnienie głównych czynników ryzyka chorób układu sercowonaczyniowego w Polsce. Wyniki badania NATPOL PLUS. Kard Pol 2004; 64 (supl. 4): 5-22.

19. Locke GR 3rd, Talley NJ, Fett SL, et al. Prevalence and clinical spectrum of gastroesophageal reflux: a population-based study in Olmsted County, Minnesota. Gastroenterology 1997; 112: 1448-56.

20. Watson DI, Lally CJ. Prevalence of symptoms and use of medication for gastroesophageal reflux in an Australian community. World I Surg 2009; 33: 88-94.

21. Stanghellini V, Reyniers G, Beerse LP. A European survey of constipation and related behavior in the general population. Gastroenterology 2000; 118: A720.

22. Talley NJ, Weaver AL, Zinsmeister AR, Melton LJ 3rd. Functional constipation and outlet delay: a population-based study. Gastroenterology 1993; 105: 781-90.

23. Talley NJ, O'Keefe EA, Zinsmeister AR, Melton LJ 3rd. Prevalence of gastrointestinal symptoms in the elderly: a populationbased study. Gastroenterology 1992; 102: 895-901. 